\title{
Synthesis of Cu(II), Ni(II), Co(II), and Mn(II) Complexes with Ciprofloxacin and Their Evaluation of Antimicrobial, Antioxidant and Anti-Tubercular Activity
}

\author{
Ketan S. Patel ${ }^{1}$, Jiten C. Patel ${ }^{1}$, Hitesh R. Dholariya ${ }^{1}$, Vishal K. Patel ${ }^{2}$, Kanuprasad D. Patel ${ }^{1 *}$ \\ ${ }^{1}$ Chemistry Department, V. P. \& R. P. T. P. Science College, Sardar Patel University, Gujarat, India \\ ${ }^{2}$ Chemistry Department, Shree P. M. Patel College of Peramedical Science \& Technology, Sardar Patel University, Gujarat, India \\ Email: *drkdpatel64@yahoo.co.in
}

Received June 20, 2012; revised July 21, 2012; accepted August 10, 2012

\begin{abstract}
$\mathrm{Co}(\mathrm{II}), \mathrm{Ni}(\mathrm{II}), \mathrm{Cu}(\mathrm{II})$ and $\mathrm{Mn}(\mathrm{II})$ complexes synthesized by reflux of 6-bromo-3-(3-(4-chlorophenyl)acryloyl)-2Hchromen-2-one, Ciprofloxacin and various transition metal. ${ }^{1} \mathrm{H},{ }^{13} \mathrm{C}$, IR and ESI Mass confirm the formation of ligand. The metal complexes were characterized on the basis of various spectroscopic techniques like IR studies and elemental analysis while the geometry of complexes was octahedral which is confirmed by electronic spectra and thermogravimetric analysis. The compounds were subjected to antimicrobial, antioxidant and anti-tubercular activity screening using serial broth dilution method and Minimum Inhibitory Concentration (MIC) is determined. Mn(II) complex has shown significant antifungal activity with an MIC of $6.25 \mu \mathrm{g} / \mathrm{ml}$ while $\mathrm{Cu}(\mathrm{II})$ complex is noticeable for antibacterial activity at the same concentration. Anti-TB activity of the ligand has enhanced on complexation with $\mathrm{Ni}(\mathrm{II})$ and $\mathrm{Co}(\mathrm{II})$ ions. While $\mathrm{Ni}(\mathrm{II})$ complex shows superior antioxidant activity than other complexes.
\end{abstract}

Keywords: Transition Metal Complex; Ciprofloxacin; Biological Activity

\section{Introduction}

The development of sensitive chemosensors is an active field of research in recent years because of their potential application in clinical biochemistry as well as analytical chemistry and environmental science [1-3]. Coumarins are wide spread in nature, also the biological properties of different coumarins and their derivatives are well known-they include anticoagulant, antiproliferative, antimicrobial, spasmolytic, antitumor, antioxidant, etc. activities [4-6].

The spectrum of activity of these compounds has become increasingly broad, especially since the introduction of a fluorine atom at position 6 (fluoroquinolones) [7]. In 2002, Turel [8] reviewed the synthesis, physico-chemical properties, and structural characteristics of several binary and ternary fluoroquinolone compounds, together with their biological activity. Ciprofloxacin [CF, 1-cyclopro-pyl-6-fluoro-1,4-dihydro-4-oxo-7-(1-piperaz-inil) -3-quinolone car-boxylic acid], is a second generation fluoroquinolone that was synthesized for first time in 1987 [7]. A well known antibacterial drug with a wide spectrum of activity, it is extremely useful for the treatment of a variety of infections [8,9]. Quinolones are a group of synthetic antibacterial agents now in clinical use already for over thirty years and ciprofloxacin is one of the widely used representatives [10,11]. The interactions of quinolones and metal ions have been thoroughly studied especially due to the interesting biological and chemical properties Ciprofloxacin can usually act as a bidentate ligand through the pyridone oxygen and one carboxylate oxygen. In the literature, diverse transition metal complexes of ciprofloxacin have been structurally characterized.

It is well known that metal ions present in complexes accelerate the drug action and the efficacy of the organic therapeutic agents [12]. The pharmacological efficiencies of metal complexes depend on the nature of the metal ions and the ligands [13]. It is declared in the literature that different ligands and different complexes synthesized from same ligands with different metal ions possess different biological properties $[12,14,15]$. So, there is an increasing requirement for the discovery of new compounds having antimicrobial, antioxidant and anti tubercular activities. The newly prepared compounds may be more effective than known others in terms of their biological activities and possibly display their efficiencies with a distinct mechanism from those of well known, Also we describes the synthesis of $\mathrm{Cu}(\mathrm{II}), \mathrm{Ni}(\mathrm{II}), \mathrm{Co}(\mathrm{II})$ and $\mathrm{Mn}(\mathrm{II})$ complexes from bromocoumarin and ciprofloxacin as ligand. For characterization of the compounds, following spectroscopic and analytical techniques were employed: IR, NMR, TGA and elemental analyses. 


\section{Experimental}

\subsection{Materials}

All reagents were of analytical reagent (AR) grade purchased commercially from Spectro Chem. Ltd., Mumbai-India and used without further purification. Solvents employed were distilled, purified and dried by standard procedures prior to use [15]. Clioquinol was purchased from Agro Chemical Division, Atul Ltd., Valsad-India. The metal nitrates used were in hydrated form.

\subsection{Physical Measurements}

All reactions were monitored by thin-layer chromatography (TLC on alluminium plates coated with silica gel $60 \mathrm{~F}_{254}, 0.25 \mathrm{~mm}$ thickness, E. Merck, Mumbai-India) and detection of the components were measured under UV light or explore in Iodine chamber. Carbon, hydrogen and nitrogen were estimated by elemental analyzer PerkinElmer, USA 2400-II CHN analyzer. Metal ion analyses was carry out by the dissolution of solid complex in hot concentrated nitric acid, further diluting with distilled water and filtered to remove the precipitated organic ligands. Remaining solution was neutralized with ammonia solution and the metal ions were titrated against EDTA. ${ }^{1} \mathrm{H}$ and ${ }^{13} \mathrm{C}$ NMR measurements were carried out on Advance-II 400 Bruker NMR spectrometer, SAIF, Chandigarh. The chemical shifts were measured with respect to TMS which used as internal standard and DMSO- $d_{6}$ used as solvent. Infrared spectra of solids were recorded in the region $400-4000 \mathrm{~cm}^{-1}$ on a Nicolet Impact 400D Fourier-Transform Infrared Spectrophotometer using $\mathrm{KBr}$ pellets. Melting point of the ligands and metal complexes were measured by open capillary tube method. Thermal decomposition (TG) analysis was obtained by a model Diamond TGA, PerkinElmer, USAThe experiments were performed in $\mathrm{N}_{2}$ atmosphere at a heating rate of $20^{\circ} \mathrm{C} \mathrm{min}{ }^{-1}$ in the temperature range $30^{\circ} \mathrm{C} \mathrm{-}$ $800^{\circ} \mathrm{C}$.

\subsection{Synthesis of 6-Bromo-3-acetyl Coumarin}

6-Bromo-3-acetyl coumarin was prepared according to the reported method [16]. A mixture of 6-bromo salicylaldhyde (12.2 g, $0.1 \mathrm{~mol})$, ethylacetoacetate (13.0 g, 0.1 $\mathrm{mol}$ ) and 3 to 4 drop piperidine were stirred for 10 mins. at room temperature in a $100 \mathrm{ml}$ round bottom flask. After 10 mins. it was heated for 30 mins in water bath. A yellow solid obtained was taken out and washed with cold ether. It was recrystallized from chloroform-hexane. Yield: 92\%; M.p. $119.5^{\circ} \mathrm{C}$.

\subsection{Synthesis of 2.4.1 Synthesis of 6-Bromo-3-cinnamoyl-2H-chromen-2-one (L)}

The neutral bidentate ligands were synthesized using
Claisen-Schmidt condensation [17]. General procedure for synthesis of the ligands (L) is shown in Scheme 1.

The ligands were characterized using elemental analysis. In a $100 \mathrm{ml}$ round bottom flask 6-bromo 3-acetyl coumarin (0.01 mol, $1.88 \mathrm{~g})$ and 4-Chloro benzaldehyde $(0.015 \mathrm{~mol})$ were taken in $15 \mathrm{ml}$ of pyridine. Catalytic amount of piperidine $(1.0 \mathrm{ml})$ was added and the reaction mixture was stirred for $10 \mathrm{~min}$ at room temperature. After clear solution obtained, the reaction mixture was refluxed on oil bath. Completion of reaction was checked by TLC using mobile phase Ethyl acetate:Hexane (7:3). After the completion of reaction, subsequently it was allowed to room temperature. Afterwards it was pour into ice-cold water and adjust the $\mathrm{pH} 4$ - 5 using diluted $\mathrm{HCl}$. A solid product separated out was filtered off, later on washed with cold ethanol and dried in air. It was recrystallized from ethanol. Yield: $76 \%$, M.p.: $164^{\circ} \mathrm{C}-165^{\circ} \mathrm{C}$. FT-IR $\left(\mathrm{KBr}, \mathrm{cm}^{-1}\right): v(\mathrm{C}=\mathrm{O}, \alpha, \beta$-unsaturated ketone $)$ $1621, v(\mathrm{C}=\mathrm{O}$, lactone carbonyl of coumarin) 1738,1031 , (p-substituted C-Cl). ${ }^{1} \mathrm{H}$ NMR (DMSO-d $\left.{ }^{6} 400 \mathrm{MHz}\right) \delta$ : $6.81(1 \mathrm{H}, \mathrm{d}, \mathrm{CH}=\mathrm{CH}-$ protons $), 7.34(2 \mathrm{H}, \mathrm{d}, \mathrm{CH}=\mathrm{CH}-$ protons), $7.58(2 \mathrm{H}, \mathrm{d}, \mathrm{CH}=\mathrm{CH}$-protons $), 7.78-8.08(3 \mathrm{H}$, $\mathrm{m}$, three aromatic protons $), 8.12(1 \mathrm{H}, \mathrm{d}, \mathrm{CH}=\mathrm{CH}-$ protons), 8.59 (1H, s, C $4-\mathrm{H}) .{ }^{13} \mathrm{C}$ NMR (DMSO-d ${ }^{6} 100 \mathrm{MHz}$ ) $\delta: 118.7,119.4,124.6,125.1,128.2,129.7,129.3,133.1$, $133.8,130.2,134.9,142.6$ (12 different types of aromatic carbons $), 147.6(\mathrm{C}-4), 152.3(\mathrm{C}-9), 159.7(\mathrm{C}=\mathrm{O}$, lactone carbonyl of coumarin), $183.8(\mathrm{C}=\mathrm{O}, \alpha, \beta$-unsaturated ketone). MS (ESI) $m / z 390.0[\mathrm{M}+\mathrm{H}]^{+}, 392.0[\mathrm{M}+\mathrm{H}]^{2+}$, $394.0[\mathrm{M}+\mathrm{H}]^{4+}$; Elemental analysis found (\%): C, 55.27; $\mathrm{H}, 2.41$; Calculated for $\mathrm{C}_{18} \mathrm{H}_{10} \mathrm{BrClO}_{3}$ (389.63): C, 55.49; H, 2.59 (Figures 1 and 2).

\subsection{Synthesis of Metal Complexes}

An aqueous solution of $\mathrm{Cu}\left(\mathrm{NO}_{3}\right)_{2} \cdot 3 \mathrm{H}_{2} \mathrm{O}$ salt $(10 \mathrm{mmol})$ was added into ethanolic solution of ligand (L) $(10 \mathrm{mmol})$ and subsequently an ethanolic solution of ciprofloxacin (10 mmol) was added with continuous stirring. Then the $\mathrm{pH}$ was adjusted in between 4.5 - 6.0 by addition of diluted $\mathrm{NH}_{4} \mathrm{OH}$ solution. The resulting solution was refluxed for $5 \mathrm{hrs}$ and then heated over a steam bath to evaporate up to half of the volume. The reaction mixture was kept overnight at room temperature. A fine coloured crystalline product was obtained. The obtained product

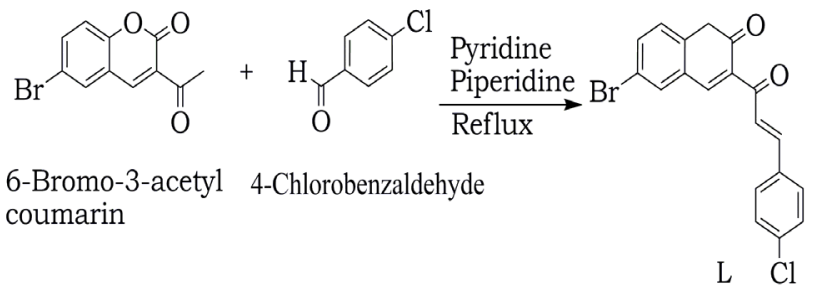

Scheme 1. Procedure for synthesis of ligands (L). 


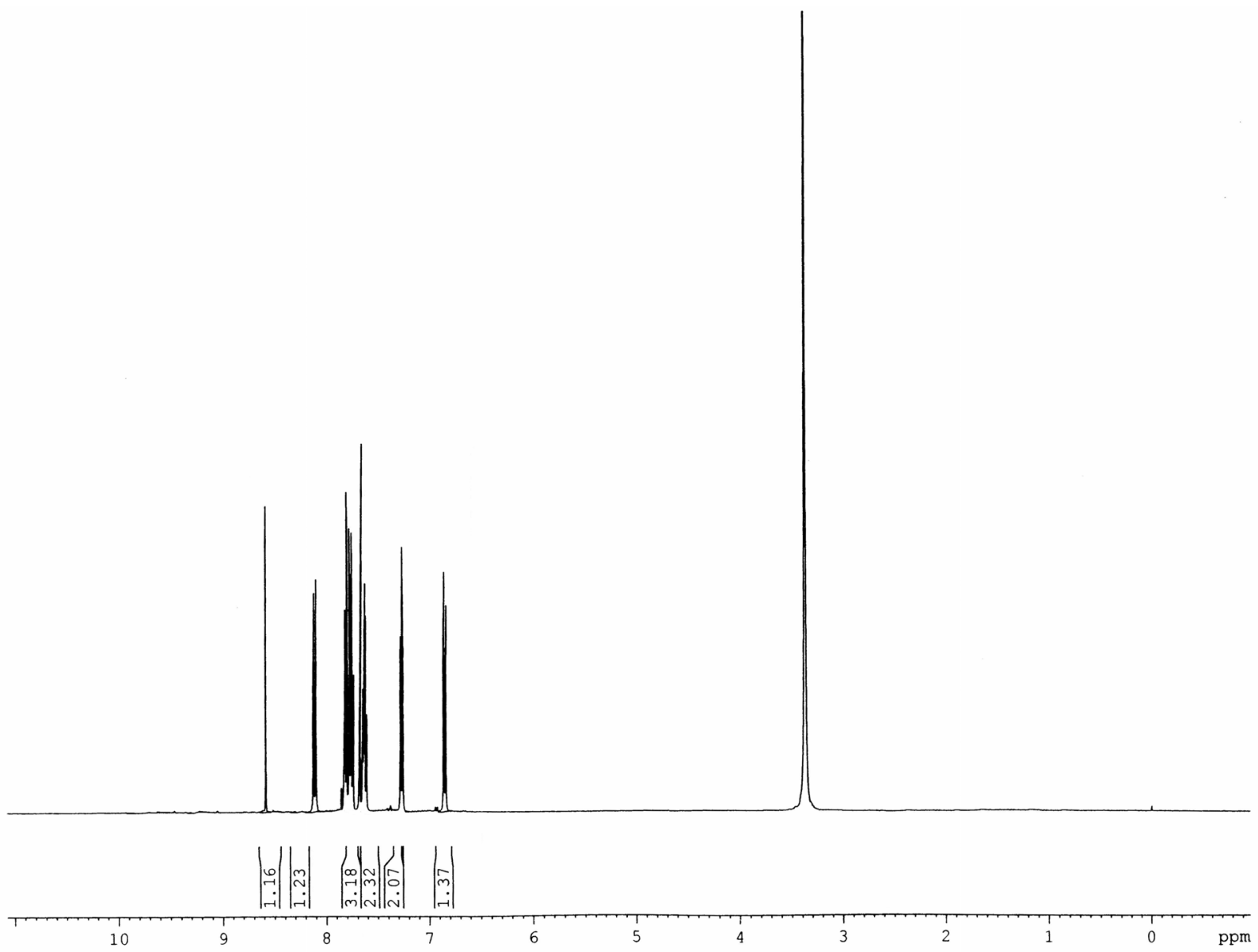

Figure 1. ${ }^{1} \mathrm{H}$-NMR spectrum of $L$.

was washed with ether and dried over vacuum desiccators. Complexes $\mathrm{Ni}(\mathrm{II}), \mathrm{Co}(\mathrm{II})$ and $\mathrm{Mn}$ (II) was prepared according to same method and their physicochemical parameters are summarized in Table 1. The synthetic protocol of complexes is shown in Scheme 2.

\subsection{Antimicrobial Activity}

The synthesized ligand and corresponding metal(II) complexes were screened in vitro for their antibacterial activity against two Gram( ${ }^{+}$ve) Streptococcus pyogenes, Bacillus subtilis and two Gram(-ve) Escherichia coli, Pseudomonas aeruginosa, where antifungal against Candida albicans and Aspergillus niger using the brothdilution method [18]. All the ATCC culture was collected from institute of microbial technology, Bangalore. 2\% Luria broth solution was prepared in distilled water while, $\mathrm{pH}$ of the solution was adjusted to $7.4 \pm 0.2$ at room temperature and sterilized by autoclaving at $15 \mathrm{lb}$ pressure for 25 mins. The tested bacterial and fungal strains were prepared in the luria broth and incubated at $37^{\circ} \mathrm{C}$ and $200 \mathrm{rpm}$ in an orbital incubator for overnight. Sample solutions were prepared in DMSO for concentration $200,150,100,50,25,12.5,6.25$ and $3.125, \mu \mathrm{g} / \mathrm{ml}$. The standard drug solution of Streptomycin (antibacterial drug) and Nystatin (antifungal drug) were prepared in DMSO. Serial broth micro dilution was adopted as a reference method. $10 \mu \mathrm{l}$ solution of test compound was inoculated in $5 \mathrm{ml}$ luria broth for each concentration respectively and additionally one test tubes was kept as control. Each of the test tubes was inoculated with a suspension of standard microorganism to be tested and incubated at $35^{\circ} \mathrm{C}$ for $24 \mathrm{hrs}$. At the end of the incubation period, the tubes were examined for the turbidity. Turbidity in the test tubes indicated that microorganism growth has not inhibited by the antibiotic contained in the medium at the test concentration. The antimicrobial activity tests were run in triplicate.

\subsection{Anti-Tubercular Activity}

Test compounds were evaluated for in vitro antimycobacterial activity. The MICs were determined and interpreted for $M$. tuberculosis $\mathrm{H} 37 \mathrm{Rv}$ according to the procedure of the approved microdilution reference method of antimicrobial susceptibility testing [19]. Compounds were taken at concentrations of $100,50,25,12.56 .25$ and $3.125 \mu \mathrm{g} / \mathrm{ml}$ in 2\% DMF. M. tuberculosis H37Rv 
Table 1. Analytical and physical parameters of complex.

\begin{tabular}{|c|c|c|c|c|c|c|c|c|}
\hline \multirow{2}{*}{ Comp. } & \multicolumn{4}{|c|}{ Elemental analyses, $\%$ found (required) } & \multirow{2}{*}{$\begin{array}{l}\text { M.p. } \\
\left({ }^{\circ} \mathrm{C}\right)\end{array}$} & \multirow{2}{*}{$\begin{array}{l}\text { Yield } \\
(\%)\end{array}$} & \multirow{2}{*}{$\begin{array}{l}\text { Molecular } \\
\text { weight }\end{array}$} & \multirow{2}{*}{$\mu_{\text {eff }}$ (B.M.) } \\
\hline & $\mathrm{C}$ & $\mathrm{H}$ & $\mathrm{N}$ & Metal(II) & & & & \\
\hline $\mathrm{Cu}(\mathrm{II})$ & $50.16(50.25)$ & $3.75(3.86)$ & $4.89(5.02)$ & $7.45(7.60)$ & $>350$ & 72 & 836.54 & 1.84 \\
\hline $\mathrm{Ni}(\mathrm{II})$ & $50.40(50.54)$ & $3.74(3.88)$ & $4.87(5.05)$ & $6.93(7.06)$ & $>350$ & 76 & 831.69 & 3.12 \\
\hline $\mathrm{Co}(\mathrm{II})$ & $50.42(50.53)$ & $3.78(3.88)$ & $5.86(5.05)$ & $6.98(7.08)$ & $>300$ & 63 & 831.93 & 3.88 \\
\hline $\operatorname{Mn}(\mathrm{II})$ & $50.65(50.77)$ & $3.78(3.90)$ & $4.97(5.08)$ & $6.50(6.64)$ & $>350$ & 70 & 827.94 & 5.92 \\
\hline
\end{tabular}<smiles>O=C(/C=C/c1ccc(Cl)cc1)c1cc2cc(Br)ccc2oc1=O</smiles>

6-bromo-3-(3-(4-chlorophenyl) acryloyl)-2H-chromen-2-one ( $\mathrm{L}$

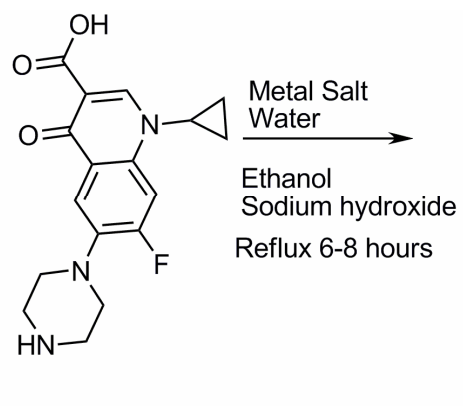

Ciprofloxacin

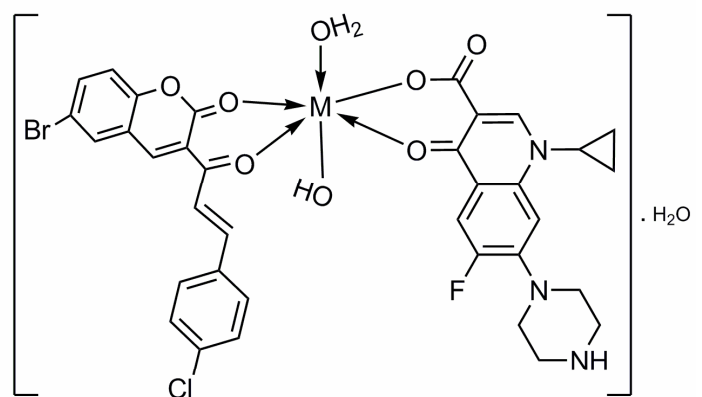

Metal(II) Complexes (C)

Scheme 2. General procedure for synthesis of complexe (C).

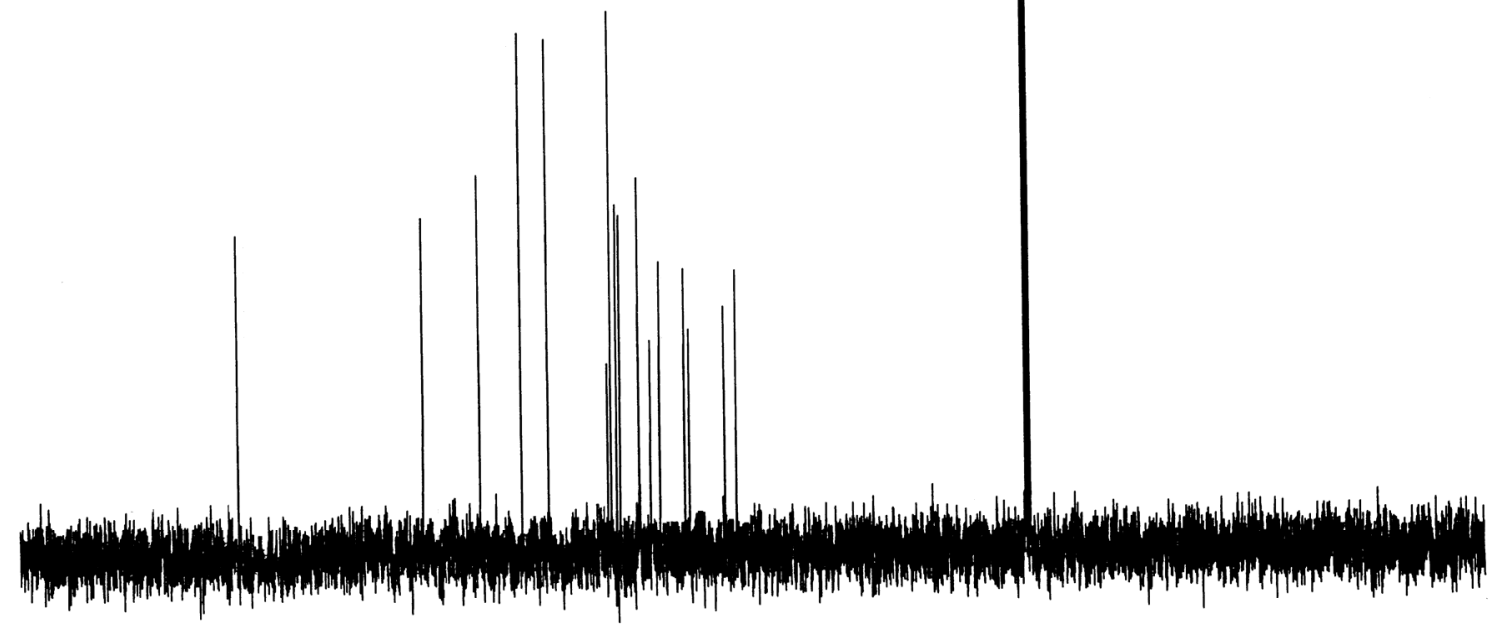

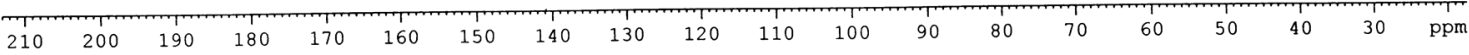

Figure 2. ${ }^{13} \mathrm{C}-\mathrm{NMR}$ spectrum of $\mathrm{L}$. 
strain was used in Middle brook 7H-9 broth which was inoculated with standard as well as test compounds and incubated at $37^{\circ} \mathrm{C}$ for 4 weeks. The bottles were inspected for growth twice a week for a period of 3 weeks. Readings were taken at the end of fourth week. The appearance of turbidity was considered as bacterial growth and indicates resistance to the compound. The growth was confirmed by making a smear from each bottle and performing a Zn stain. Test compounds were compared to reference drugs Ethambutol (MIC $=3.25 \mu \mathrm{g} / \mathrm{ml})$ and the antimicrobial and anti-tubercular activity tests were run in triplicate.

\subsection{Antioxidant Studies}

Ferric reducing antioxidant power (FRAP) was measured by a modified method of Benzie and Strain [20]. The antioxidant potentials of the compounds were estimated as their power to reduce the TPTZ-Fe(III) complex to TPTZ-Fe(II) complex (FRAP assay), which is simple, fast, and reproducible. FRAP working solution was prepared by mixing a $25.0 \mathrm{ml}, 10 \mathrm{~mm}$ TPTZ solution in 40 $\mathrm{mm} \mathrm{HCl}, 20 \mathrm{~mm} \mathrm{FeCl}{ }_{3} \cdot 6 \mathrm{H}_{2} \mathrm{O}$ and $25 \mathrm{ml}, 0.3 \mathrm{M}$ acetate buffer at $\mathrm{pH} 3.6$. A mixture of $40.0 \mathrm{ml}, 0.5 \mathrm{~mm}$ sample solution and $1.2 \mathrm{ml} \mathrm{FRAP} \mathrm{reagent} \mathrm{was} \mathrm{incubated} \mathrm{at} 37^{\circ} \mathrm{C}$ for 15 mins. Absorbance of intensive blue colour [Fe(II)-TPTZ] complex was measured at $593 \mathrm{~nm}$. The ascorbic acid was used as a standard antioxidant compound. The results are expressed as ascorbic equivalent (mmol/100 $\mathrm{g}$ of dried compound). All the tests were run in triplicate and are expressed as the mean and standard deviation (SD).

\section{Result and Discussion}

The synthesized complexes were characterized by elemental analysis and FTIR. The metal ion in their complexes was determined after mineralization. The metal content in chemical analysis was estimated by complexometrically [21]. However, ligand and its complexes have been screened for their in vitro antimicrobial antioxidant and anti-tubercular activities, while geometry of the complexes was confirmed from electronic spectra and TGA.

\subsection{Elemental Analysis}

The analytical and physiochemical data of the complexes are summarized in Table 1. The experimental data were in very good agreement with the calculated ones. The complexes were colored, insoluble in water and commonly organic solvents while soluble in DMSO as well as stable in air.

\subsection{FT-IR Spectra}

The analysis of the FT-IR spectra of both ligands and complex provided information on the coordination mode between the ligands and the metal ion IR Spectra. The IR Spectra of ligand (L) and its Co(II) complex are given in Figures 3 and 4 respectively, while the IR spectral data of all complexes are summarized in Table 2. The infrared spectra of fluoroquinolones are quite complex due to the presence of the numerous functional groups in the molecules, therefore their interpretation is based on the most typical vibrations being the most important region in the IR spectra of fluoroquinolones between $\approx 1800 \mathrm{~cm}^{-1}$ and $\approx 1300 \mathrm{~cm}^{-1}$ [22]. Spectra of the mixed-ligand $\mathrm{Cu}(\mathrm{II})$ complexes reveals that a broad band in the region $\approx 3420$ $-3460 \mathrm{~cm}^{-1}$ due to stretching vibration of $\mathrm{OH}$ group. The $v(\mathrm{C}=\mathrm{O})$ stretching vibration band appears at $\approx 1708 \mathrm{~cm}^{-1}$ in the spectra of ciprofloxacin, and the complexes show this band at $\approx 1628 \mathrm{~cm}^{-1}$; this band shifted towards lower energy, suggesting that coordination occurs through the pyridone oxygen atom [23]. The strong absorption bands obtained at $\approx 1625$ and $\approx 1380 \mathrm{~cm}^{-1}$ in ciprofloxacin are observed at $\approx 1570-1580$ and $\approx 1345-1375 \mathrm{~cm}^{-1}$ for $v(\mathrm{COO})_{\mathrm{a}}$ and $v(\mathrm{COO})_{\mathrm{s}}$ in the complexes, respectively; in the present case the separation frequency $\Delta v>200 \mathrm{~cm}^{-1}(\Delta v$ $\left.=v(\mathrm{COO})_{\mathrm{a}}-v(\mathrm{COO})_{\mathrm{s}}\right)$, suggesting unidentate binding of

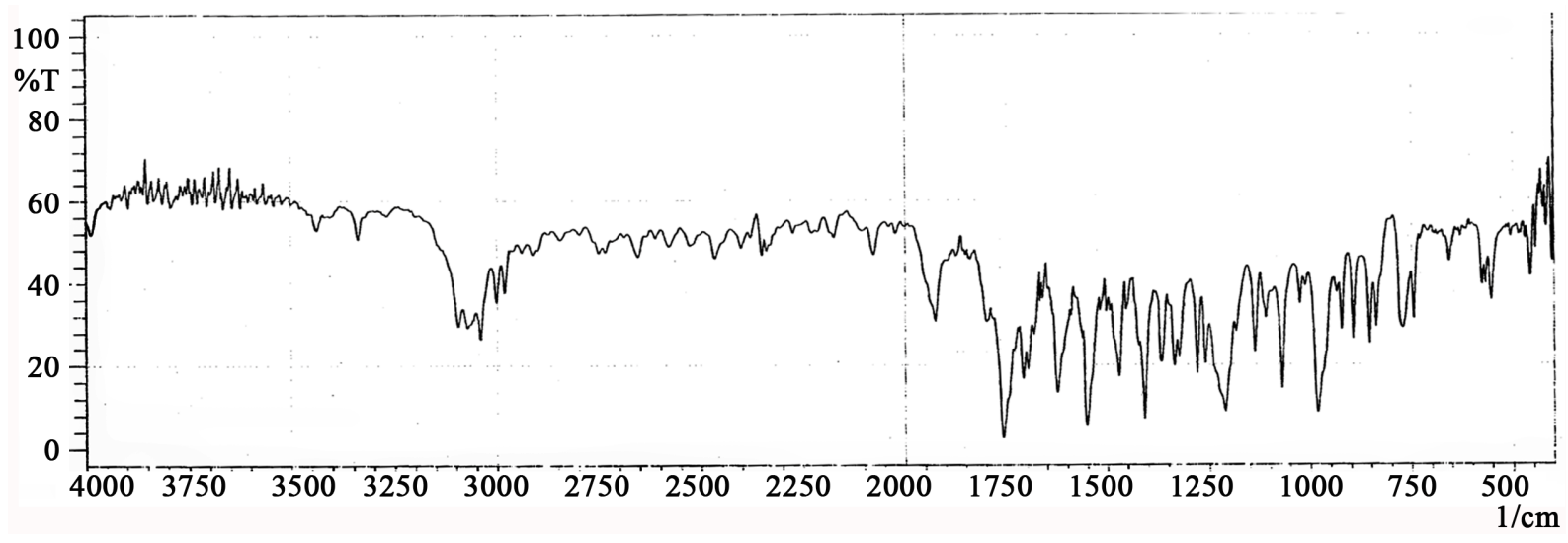

Figure 3. FT-IR spectrum of L. 


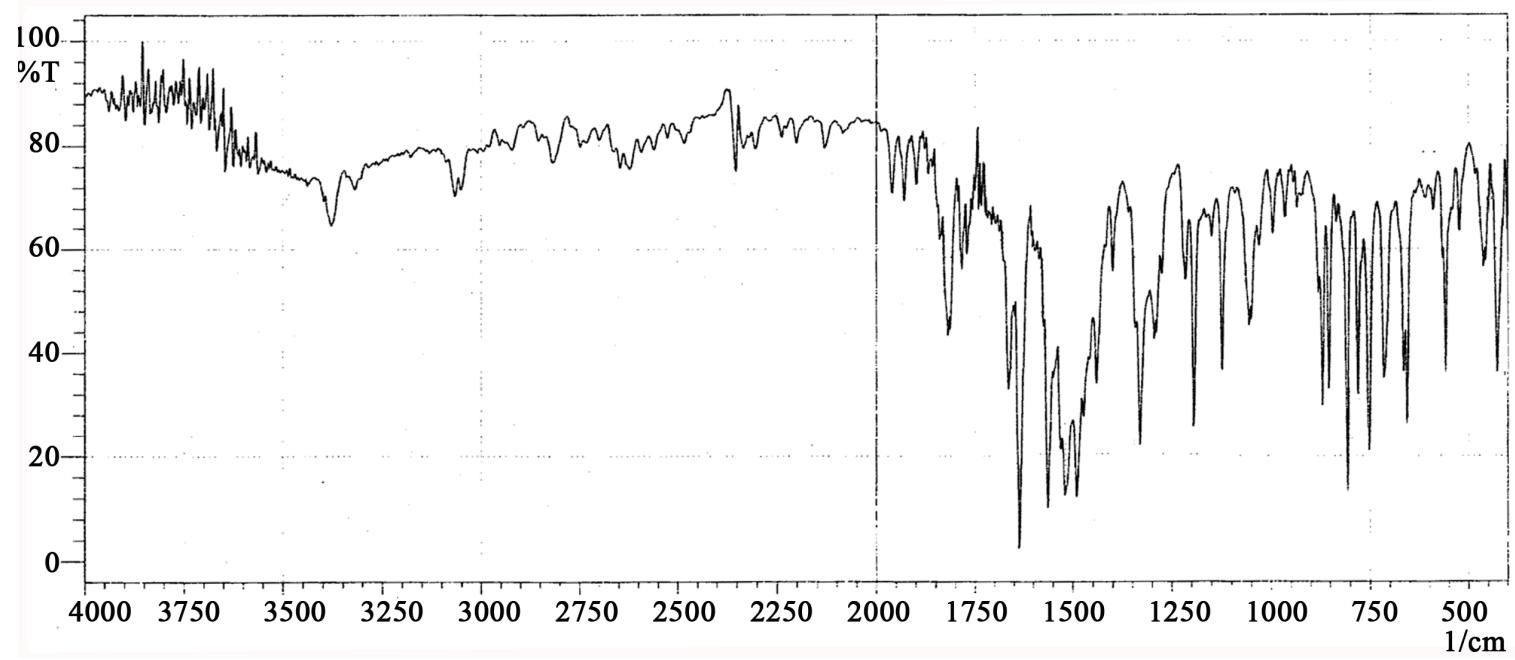

Figure 4. FT-IR spectrum of complex Co(II).

Table 2. FT-IR data of synthesized compounds.

\begin{tabular}{cccccccc}
\hline Comp. & $v(\mathrm{O}-\mathrm{H})^{\mathrm{br}} \mathrm{cm}^{-1}$ & $v(\mathrm{COO}) \mathrm{sy}$ & $v(\mathrm{COO})$ asy & $\begin{array}{c}\alpha, \beta \text {-unsaturated } \\
v(\mathrm{C}=\mathrm{O})^{\mathrm{s}} \mathrm{cm}^{-1}\end{array}$ & $\begin{array}{c}\text { lactone carbonyl } \\
v(\mathrm{C}=\mathrm{O})^{\mathrm{s}} \mathrm{cm}^{-1}\end{array}$ & $\begin{array}{c}v(\mathrm{C}=\mathrm{O}) \\
\text { of pyridone }\end{array}$ & $v(\mathrm{M}-\mathrm{O})^{\mathrm{w}} \mathrm{cm}^{-1}$ \\
\hline $\mathrm{C}^{1}$ & 3435 & 1371 & 1590 & 1605 & 1722 & 1619 & 525 \\
$\mathrm{C}^{2}$ & 3132 & 1373 & 1586 & 1609 & 1732 & 1620 & 512 \\
$\mathrm{C}^{3}$ & 3428 & 1375 & 1582 & 1606 & 1730 & 1630 & 510 \\
$\mathrm{C}^{4}$ & 3445 & 1372 & 1587 & 1608 & 1725 & 1624 & 528 \\
\hline
\end{tabular}

${ }^{\mathrm{s}}=$ strong, ${ }^{\mathrm{w}}=$ weak, ${ }^{\text {br }}=$ broad

the carboxylato group [24,25]. The IR spectra of the coumarin derivatives shows $\approx 1612 \mathrm{~cm}^{-1}$ and $\approx 1745 \mathrm{~cm}^{-1}$ bands corresponding to $\alpha, \beta$-unsaturated ketone and lactone carbonyl ketone respectively, on complexation these peaks shifted to a lower frequency $\approx 1600 \mathrm{~cm}^{-1}$ and $\approx 1735 \mathrm{~cm}^{-1}$ due to complex formation. In all the complexes, a new band is seen in the $\approx 538-546 \mathrm{~cm}^{-1}$ region, which is probably due to the formation of the weak band observed in the $\approx$ $430-455 \mathrm{~cm}^{-1}$ range can be attributed to $v(\mathrm{M}-\mathrm{O})$ [26-27].

\subsection{Thermal Studies of $\mathrm{Cu}(\mathrm{II})$ Complexes}

The Thermal behaviour of the complexes was studied using TG whereas TG curves corresponding to the complex $\left(\mathrm{C}^{1}\right)$ is represented in Figure 5. The thermal decomposition data for all complexes are given in Table $\mathbf{3}$. The thermal decomposition occurs in four steps in air are observed. According to the mass losses, the following degradation pattern might be proposed for complex $\left[\mathrm{Cu}(\mathrm{L})(\mathrm{CF})\left(\mathrm{H}_{2} \mathrm{O}\right) \mathrm{OH}\right] \cdot \mathrm{H}_{2} \mathrm{O}\left(\mathrm{C}^{1}\right)$ is represented in Scheme 3. All the compounds decompose with time respectively. Thermal decomposition started by dehydration process and was accompanied by endothermic effect be- tween $80^{\circ} \mathrm{C}-110^{\circ} \mathrm{C}$, which was due to loss of one lattice water molecules in first step. The observed mass loss was $2.05 \%$ which was nearly equal to theoretical value $2.15 \%$. In the second step, weight loss occur at $220^{\circ} \mathrm{C}-250^{\circ} \mathrm{C}$ corresponds to loss of one coordinated water and one al of coordinated Ciprofloxacin as well as ligand (coumarins) respectively. As temperature raise, the intermediate complexes $[\mathrm{Cu}(\mathrm{L})(\mathrm{CF})]\left(350^{\circ} \mathrm{C}-440^{\circ} \mathrm{C}\right)$ and $[\mathrm{Cu}(\mathrm{CF})]\left(500^{\circ} \mathrm{C}-640^{\circ} \mathrm{C}\right)$ convert to $\mathrm{CuO}$ residue of fragments. The observed mass loss for third and fourth stage was $37.68 \%$ (calc. $39.60 \%$ ) and $41.43 \%$ (calc. $46.57 \%$ ) respectively. and remaining weight is in good agreement with copper oxide $(\mathrm{CuO})$.

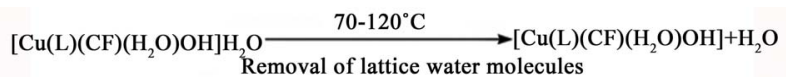

$$
\begin{aligned}
& {\left[\mathrm{Cu}(\mathrm{L})(\mathrm{CF})\left(\mathrm{H}_{2} \mathrm{O}\right)(\mathrm{OH})\right] \frac{140-260^{\circ} \mathrm{C}}{\begin{array}{l}
\text { Removal of one-OH\& } \mathrm{H}_{2} \mathrm{O} \\
\text { co-ordinated molecules }
\end{array}}[\mathrm{Cu}(\mathrm{L})(\mathrm{CF})]+\mathrm{H}_{3} \mathrm{O}_{2}}
\end{aligned}
$$

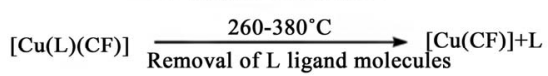

$$
\begin{aligned}
& {[\mathrm{Cu}(\mathrm{CF})] \underset{\text { Removal of } \mathrm{CF} \text { ligand molecules }}{\stackrel{380-800^{\circ} \mathrm{C}}{\longrightarrow} \text { metal residue }(\mathrm{CuO})+\mathrm{CF}}}
\end{aligned}
$$

Scheme 3. Thermal degradation pattern of $C^{1}$ 


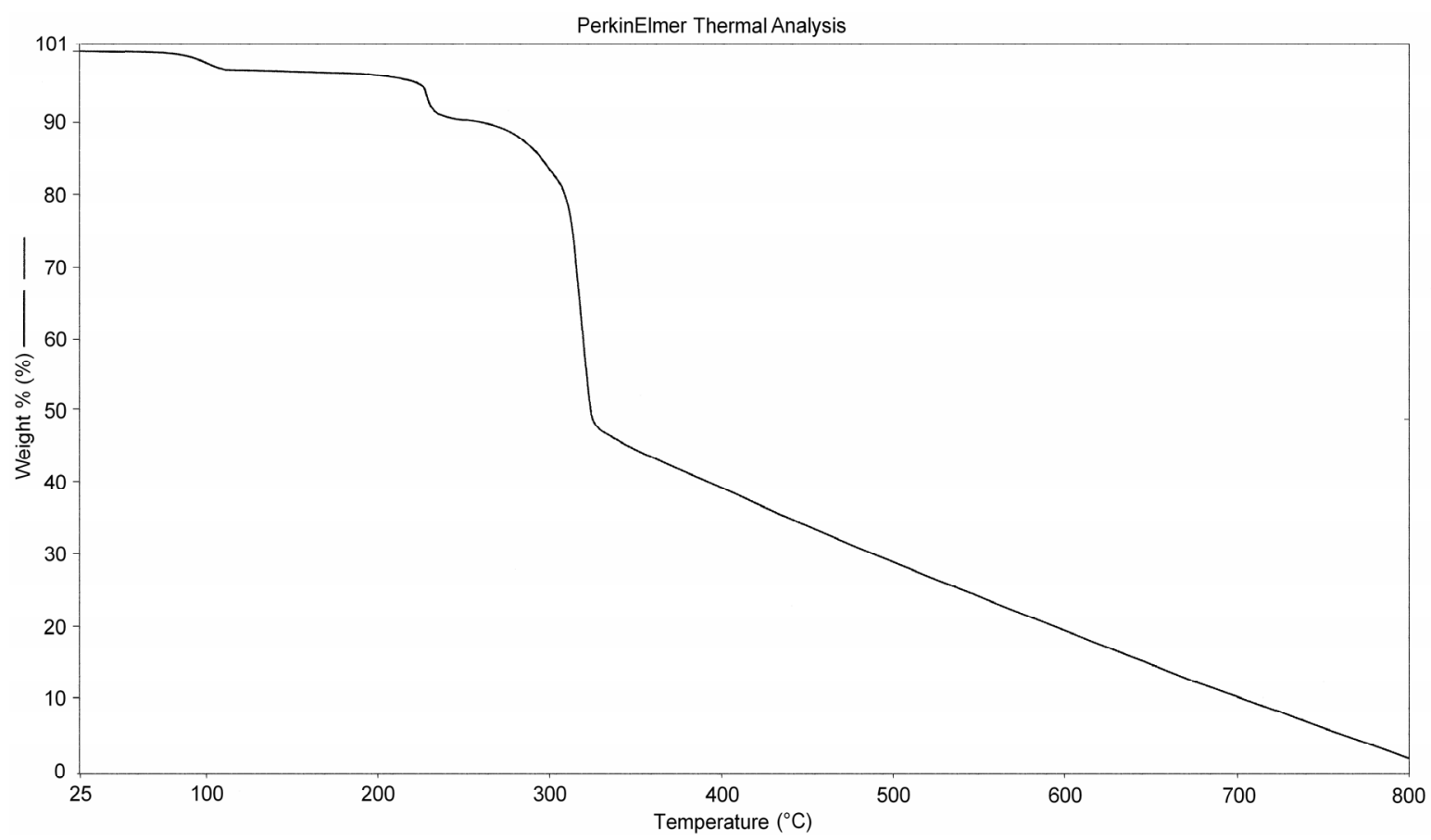

Figure 5. TGA of complex Cu(II).

Table 3. Thermoanalytical results (TG and DTG) of metal complexes.

\begin{tabular}{|c|c|c|c|c|}
\hline Complexes & $\mathrm{TG}$ range $/{ }^{\circ} \mathrm{C}$ & $\mathrm{DTG}_{\max } /{ }^{\circ} \mathrm{C}$ & Mass loss $\%$ obs. & Assignment \\
\hline \multirow{5}{*}{$\mathrm{Cu}(\mathrm{II})$} & \multirow{3}{*}{$70-380$} & 90 & 2.05 & Loss of one lattice water molecules \\
\hline & & 235 & 4.25 & Loss of one $-\mathrm{OH} \& \mathrm{H}_{2} \mathrm{O}$ molecules \\
\hline & & 348 & 37.68 & Removal of L ligand \\
\hline & \multirow{2}{*}{$380-800$} & 555 & 41.43 & Removal of Ciprofloxacin ligand \\
\hline & & $>650$ & 7.66 & Leaving $\mathrm{CuO}$ residue \\
\hline \multirow{5}{*}{$\mathrm{Ni}(\mathrm{II})$} & \multirow{3}{*}{$80-390$} & 73 & 2.12 & Loss of one lattice water molecules \\
\hline & & 218 & 4.18 & Loss of one $-\mathrm{OH} \& \mathrm{H}_{2} \mathrm{O}$ molecules \\
\hline & & 300 & 43.61 & Removal of L ligand \\
\hline & \multirow{2}{*}{$390-800$} & 540 & 39.54 & Removal of Ciprofloxacin ligand \\
\hline & & $>650$ & 7.12 & Leaving $\mathrm{NiO}$ residue \\
\hline \multirow{5}{*}{$\mathrm{Co}(\mathrm{II})$} & \multirow{3}{*}{$60-380$} & 93 & 2.15 & Loss of one lattice water molecules \\
\hline & & 248 & 4.13 & Loss of one $-\mathrm{OH} \& \mathrm{H}_{2} \mathrm{O}$ molecules \\
\hline & & 357 & 43.45 & Removal of L ligand \\
\hline & \multirow{2}{*}{$380-800$} & 550 & 38.78 & Removal of Ciprofloxacin ligand \\
\hline & & $>650$ & 7.15 & Leaving $\mathrm{CoO}$ residue \\
\hline \multirow{5}{*}{$\mathrm{Mn}(\mathrm{II})$} & \multirow{3}{*}{$90-380$} & 96 & 2.14 & Loss of one lattice water molecules \\
\hline & & 230 & 4.45 & Loss of one $-\mathrm{OH} \& \mathrm{H}_{2} \mathrm{O}$ molecules \\
\hline & & 355 & 43.57 & Removal of L ligand \\
\hline & \multirow{2}{*}{$380-800$} & 570 & 39.10 & Removal of Ciprofloxacin ligand \\
\hline & & $>650$ & 7.57 & Leaving $\mathrm{MnO}$ residue \\
\hline
\end{tabular}




\subsection{Electronic Spectra}

The $\mathrm{Cu}(\mathrm{II}), \mathrm{Ni}(\mathrm{II}), \mathrm{Co}(\mathrm{II})$, and $\mathrm{Mn}(\mathrm{II})$ complexes show magnetic moments of 1.84 . 3.12, 3.88 and 5.92 B.M. respectively which is characteristic of mononuclear, $\mathrm{Cu}(\mathrm{II})\left(\mathrm{d}^{9}, 1\right.$ unpaired electron) octahedral, $\mathrm{Ni}(\mathrm{II})\left(\mathrm{d}^{8}, 2\right.$ unpaired electrons), $\mathrm{Co}(\mathrm{II})$ ( $\mathrm{d}^{7}, 3$ unpaired electrons), and $\left(\mathrm{d}^{5}, 5\right.$ unpaired electrons) complexes [28].

The electronic spectral data of the complexes in DMF are shown in Table 4. The $\mathrm{Cu}(\mathrm{II})$ complexes display three prominent bands. Low intensity broad band in the region $16,900-17,900 \mathrm{~cm}^{-1}$ was assigned as $10 \mathrm{Dq}$ band corresponding to ${ }^{2} \mathrm{E}_{\mathrm{g}} \rightarrow{ }^{2} \mathrm{~T}_{2 \mathrm{~g}}$ transition [29]. In addition, there was a high intensity band in the region 22,900 - 27,100 $\mathrm{cm}^{-1}$. This band is due to symmetry forbidden ligand $\rightarrow$ metal charge transfer transition [30]. The band above
$27,100 \mathrm{~cm}^{-1}$ was assigned as ligand band. Therefore distorted octahedral geometry around $\mathrm{Cu}(\mathrm{II})$ ion was suggested on the basis of electronic spectra [31]. The electronic spectrum of the $\mathrm{Ni}(\mathrm{II})$ complex exhibits three bands at $10,050,14,925$ and $23,529 \mathrm{~cm}^{-1}$, attributable to ${ }^{3} \mathrm{~A}_{2 \mathrm{~g}}(\mathrm{~F}) \rightarrow{ }^{3} \mathrm{~T}_{2 \mathrm{~g}}(\mathrm{~F})\left(v_{1}\right),{ }^{3} \mathrm{~A}_{2 \mathrm{~g}}(\mathrm{~F}) \rightarrow{ }^{3} \mathrm{~T}_{1 \mathrm{~g}}(\mathrm{~F})\left(v_{2}\right)$ and ${ }^{3} \mathrm{~A}_{2 \mathrm{~g}}(\mathrm{~F}) \rightarrow{ }^{3} \mathrm{~T}_{1 \mathrm{~g}}(\mathrm{P})\left(v_{3}\right)$ transitions, respectively, for an octahedral Ni(II) complex. The electronic spectrum of the Co(II) complex shows two bands at 15,748, 19,230 $\mathrm{cm}^{-1}$ which are assigned to ${ }^{4} \mathrm{~T}_{1 \mathrm{~g}} \rightarrow{ }^{4} \mathrm{~A}_{2 \mathrm{~g}}(\mathrm{~F})\left(\mathrm{v}_{2}\right)$ and ${ }^{4} \mathrm{~T}_{1 \mathrm{~g}}(\mathrm{~F}) \rightarrow{ }^{4} \mathrm{~T}_{1 \mathrm{~g}}(\mathrm{P})\left(\mathrm{v}_{3}\right)$ transitions, respectively, as expected for an octahedral $\mathrm{Co}(\mathrm{II})$ complex[32,33]. $\mathrm{Mn}^{2+}$ complexes show two bands in the region 18,000 - 20,000 $\mathrm{cm}^{-1}$ and a weak band in the region $23,600-24,350 \mathrm{~cm}^{-1}$ for octahedral geometry (Figure 6).

Table 4. Electronic spectral data of the complexes.

\begin{tabular}{|c|c|c|c|c|}
\hline \multirow{2}{*}{$\begin{array}{c}\text { Compounds } \\
\mathrm{Cu}(\mathrm{II})\end{array}$} & \multicolumn{2}{|c|}{ Transition band observed $\left(\mathrm{cm}^{-1}\right)$} & \multirow{2}{*}{$\begin{array}{c}\mu_{\text {eff }} \text { (B.M.) } \\
1.84\end{array}$} & \multirow{2}{*}{$\begin{array}{l}\text { Geometry } \\
\text { Octahedra }\end{array}$} \\
\hline & 17,240 & 25,200 & & \\
\hline $\mathrm{Ni}(\mathrm{II})$ & 10,050 & 14,925 & 3.12 & Octahedral \\
\hline $\mathrm{Co}(\mathrm{II})$ & 15,748 & 19,230 & 3.88 & Octahedral \\
\hline $\mathrm{Mn}(\mathrm{II})$ & 19,340 & 23,930 & 5.92 & Octahedral \\
\hline
\end{tabular}

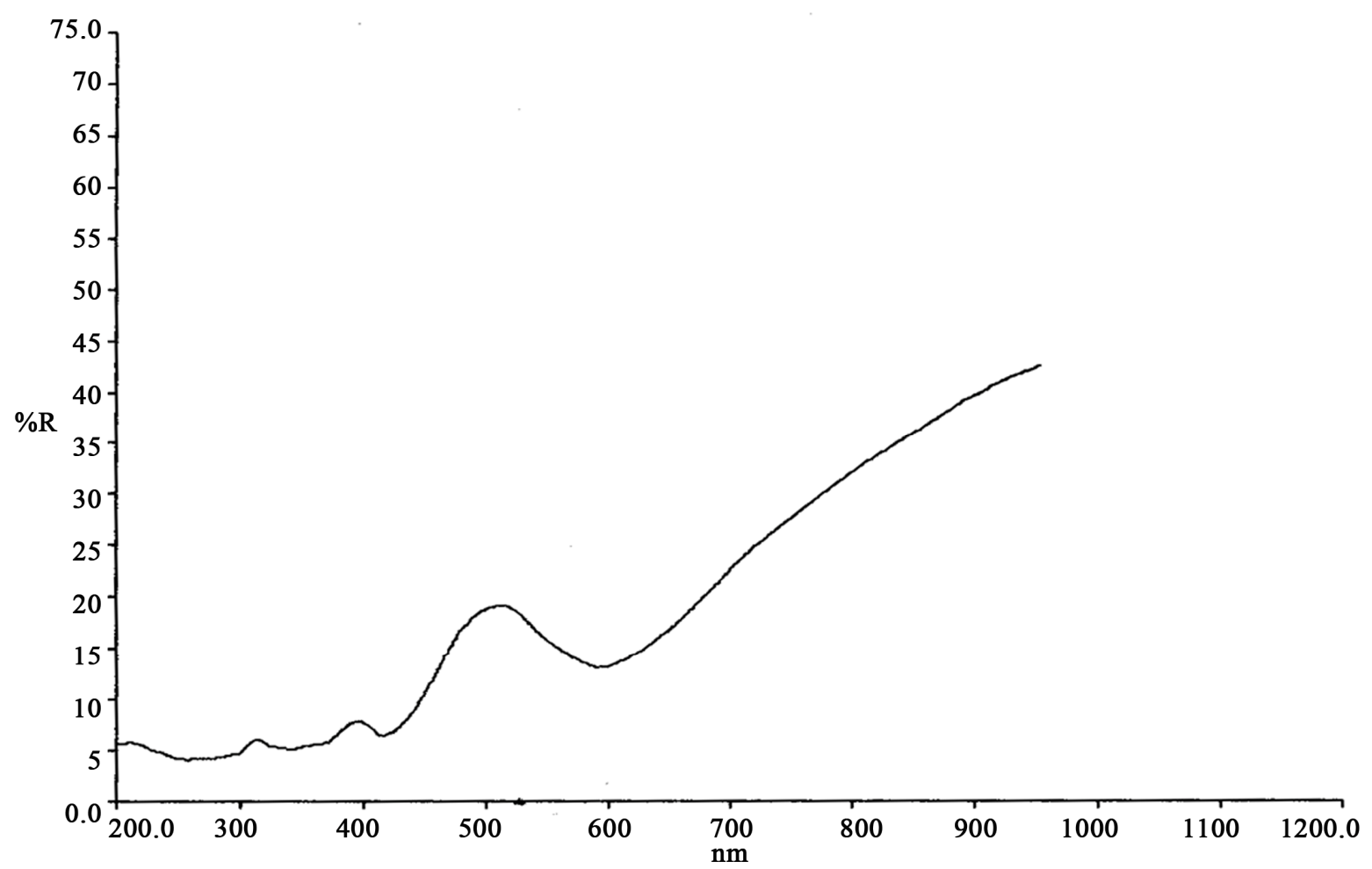

Figure 6. Electronics spectrum of complex $\mathrm{Cu}(\mathrm{II})$. 


\subsection{Antimicrobial Bioassay}

The ligand and its metal complexes were screened for their antibacterial and antifungal activities according to the respective literature protocol [34] and the results obtained are $\mathrm{p}$ [resented in Table 5. The result was compared with those of the standard drug. All the metal compared with those of the standard drug. All the metal complexes with those of the standard drug. All the metal complexes were more potent bactericides and fungicides than the ligand. Co(II) and Mn(II) complexes were much less bacterial activity than the $\mathrm{Cu}(\mathrm{II})$ and $\mathrm{Ni}(\mathrm{II})$ complex while $\mathrm{Mn}(\mathrm{II})$ complex shows superior antifungal activity compare to other complexes. From Table 5, it can be seen that the highest Antibacterial activity of $\mathrm{Cu}$ (II) complex against the bacterium B. subtilis $(3.125 \mu \mathrm{g} / \mathrm{ml})$. On the other hand, Mn(II) complex showed the best activity towards fungi against A. niger $(3.125 \mu \mathrm{g} / \mathrm{ml})$. There was a marked increase in the bacterial and fungi activities of the $\mathrm{Cu}(\mathrm{II})$ and $\mathrm{Mn}(\mathrm{II})$ complexes respectively, as compared with the free ligand and other complexes under test, which is in agreement with the antifungal and antibacterial properties of a range of $\mathrm{Cu}(\mathrm{II})$ and $\mathrm{Mn}(\mathrm{II})$ complexes evaluated against several pathogenic fungi and bacteria [35]. For many years it was believed that a trace of $\mathrm{Cu}$ (II) destroys themicrobe; however, amore recent mechanism is that activated oxygen in the surface of metal $\mathrm{Cu}$ kills the microbe because $\mathrm{Cu}$ (II) activity is weak. This enhancement of metal complexes in the activity can be explained on the basis of chelation theory [36]. Chelation reduces the polarity of the metal atom mainly because of partial sharing of its positive charge with the donor groups and possible $\pi$ electron delocalization within the whole chelate ring. Such a chelation also enhances the lipophililic character of the central metal atom, which subsequently favors its permeation through the lipid layers of cell membrane and the blocking of the metal binding sites on enzymes of microorganism. The variation in the effectiveness of different compound against different organisms depends either on the impermeability of the cell of the microbes or differences in the ribosomes of microbial cells.

\subsection{Anti-Tubercular Activity}

The Metal(II) complexes were tested for antitubercular activity in order to check the impact of coumarin moiety to with compare activity of Ethambutol (Table 5). The anti-mycobacterial activities of all the synthesized compounds are assessed against $M$. tuberculosis $\mathrm{H} 37 \mathrm{RV}$ at $3.125,6.25,12.5,25,50$ and $100 \mu \mathrm{g} / \mathrm{ml}$. The Minimum Inhibitory Concentrations of compounds compared with Ethambutol as the standard anti-TB drugs and are summarized in Table 5. Lignad show inhibition at concentration $25 \mu \mathrm{g} / \mathrm{ml}$. Ni(II) and $\mathrm{Co}(\mathrm{II})$ complexes also exhibit activity at same concentration while $\mathrm{Cu}$ (II) and $\mathrm{Mn}$ (II) complexes have shown enhancement in activity with MIC of $25 \mu \mathrm{g} / \mathrm{ml}$. None of the tested compounds have the inhibition more than standards.

\subsection{Antioxidant Studies}

A capacity to transfer a single electron i.e. the antioxidant power of all compounds was determined by a FRAP

Table 5. Antimicrobial, anti-tubercular and antioxidant results of compounds.

\begin{tabular}{|c|c|c|c|c|c|c|c|c|}
\hline \multirow{3}{*}{ Compounds } & \multicolumn{6}{|c|}{ Minimal inhibition concentration ${ }^{\text {a }}$ of microorganisms $(\mu \mathrm{g} / \mathrm{ml})$} & \multirow{3}{*}{$\begin{array}{c}\text { Antioxidant activity } \\
\text { FRAP value }(\mathrm{mmol} / 100 \mathrm{~g})\end{array}$} & \multirow{3}{*}{ Anti-tubercular activity ${ }^{\mathrm{a}}$} \\
\hline & \multicolumn{3}{|c|}{ Bacteria } & \multicolumn{3}{|c|}{ Fungi } & & \\
\hline & S.P. & B.S. & E.C. & P.A. & C. A. & A. $N$ & & \\
\hline $\mathrm{L}^{1}$ & 100 & 50 & 100 & 100 & 50 & 100 & NT & 25 \\
\hline $\mathrm{Cu}(\mathrm{II})$ & 6.25 & 3.125 & 3.125 & 6.25 & 6.25 & 12.5 & 412.0276 & 25 \\
\hline $\mathrm{Ni}(\mathrm{II})$ & 12.5 & 12.5 & 6.25 & 25 & 12.5 & 25 & 445.7542 & 6.25 \\
\hline $\mathrm{Co}(\mathrm{II})$ & 25 & 12.5 & 12.5 & 25 & 12.5 & 6.25 & 347.7034 & 12.5 \\
\hline $\mathrm{Mn}(\mathrm{II})$ & 25 & 25 & 12.5 & 25 & 25 & 3.125 & 317.276 & 25 \\
\hline Streptomycin & 0.025 & 0.025 & 0.020 & 0.020 & NT & NT & NT & NT \\
\hline Ethambutol & NT & NT & NT & NT & NT & NT & NT & 3.25 \\
\hline Flucanazole & NT & NT & NT & NT & 0.05 & 0.05 & NT & NT \\
\hline Ascorbic acid & NT & NT & NT & NT & NT & NT & 500 & NT \\
\hline
\end{tabular}

${ }^{a}$ Average value of triplicate results; ${ }^{b}$ FRAP results expressed in mm of ascorbic acid per $100 \mathrm{~g}$ of sample i.e. mmol/100g; NT = Not Tested. 
assay. The FRAP value was expressed as an equivalent of standard antioxidant ascorbic acid (mmol/100g of dried compound). FRAP values indicate that all the compounds have a ferric reducing antioxidant power. The compounds $\mathrm{Cu}(\mathrm{II})$ and $\mathrm{Ni}(\mathrm{II})$ showed relatively high antioxidant activity while compound $\mathrm{Co}(\mathrm{II})$ and $\mathrm{Mn}$ (II) shows poor antioxidant power (Table 5).

\section{Conclusion}

Here Newly the synthesised Cu(II), Ni(II), Co(II) and Mn(II) complexes from biological active Ligand (L) and ciprofloxacin. The structures of the ligand were investigated and confirmed by the elemental analysis, FT-IR, ${ }^{1} \mathrm{H}-\mathrm{NMR},{ }^{13} \mathrm{C}-\mathrm{NMR}$ and mass spectral studies. Octahedral geometry were all $\mathrm{M}(\mathrm{II})$ complexes assign on the basis of electronic, and TG analysis. All M(II) complexes tested by in vitro antimicrobial, anti-tubercular and antioxidant activity which shows fine results with an enhancement of activity on complexation with metal ions. This enhancement in the activity may be due to increased lipophilicity of the complexes. In review, the antimicrobial testing results reveal that complexes possess higher activity compared to parent ligand.

\section{Acknowledgements}

We are grateful to The Principal, and management of $\mathrm{V}$. P. \& R. P. T. P. Science College, Vallabh Vidyanagar for providing infrastructures and obligatory facilities for research. We are thankful to The Director, SICART, Vallabh Vidyanagar for analytical facilities. Authors are also grateful to The Director, SAIF-RSIC, Panjab University, Chandigarh for NMR analysis. We are articulate our appreciation to IIT-Bombay for TG and DTG scan analysis facility.

\section{REFERENCES}

[1] E. L. Que, D. W. Domaille and C. J. Chang, "Metals in Neurobiology: Probing Their Chemistry and Biology with Molecular Imaging," Chemical Reviews, Vol. 108, No. 5, 2008, pp. 1517-1549. doi:10.1021/cr078203u

[2] A. W. Czarnik, "Desperately Seeking Sensors," Chemistry \& Biology, Vol. 2, No. 7, 1995, pp. 423-428. doi:10.1016/1074-5521(95)90257-0

[3] K. W. Huang, H. Yang, Z. G. Zhou, M. X. Yu, F. Y. Li, X. Gao, T. Yi and C. H. Huang, "Multisignal Chemosensor for $\mathrm{Cr}^{3+}$ and Its Application in Bioimaging," Organic Letters, Vol. 10, No. 12, 2008, pp. 2557-2560. doi:10.1021/o1800778a

[4] I. Kostova, I. Manolov, S. Konstantinov and M. Karaivanova, "Synthesis, Physicochemical Characterisation and Cytotoxic Screening of New Complexes of Cerium, Lanthanum and Neodymium with Warfarin and Coumachlor Sodium Salts," European Journal of Medicinal Chemistry,
Vol. 34, No. 1, 1999, pp. 63-68. doi:10.1016/S0223-5234(99)80041-5

[5] I. Kostova, I. Manolov, I. Nicolova and N. Danchev, "New Metal Complexes of 4-Methyl-7-hydroxycoumarin Sodium Salt and Their Pharmacological Activity," II Farmaco, Vol. 56, No. 9, 2001, pp. 707-713. doi:10.1016/S0014-827X(01)01109-0

[6] I. Kostova, I. Manolov, I. Nicolova, S. Konstantinov and M. Karaivanova, "New Lanthanide Complexes of 4- Methyl-7-Hydroxycoumarin and Their Pharmacological Activity," European Journal of Medicinal Chemistry, Vol. 36, No. 4, 2001, pp. 339-347. doi:10.1016/S0223-5234(01)01221-1

[7] W. Martindale, "Martindale_-The Extra Pharmacopeia," 30th Edition, The Pharmaceutical Press, London, 1993.

[8] P. Ball, "The Quinolones," Academic Press, San Diego, 2000 .

[9] G. Sheehan, N. S. Y. Chew, "The History of Quinolones" In: A. R. Ronald, D. E. Low, Eds., Fluoroquinolone Antibiotics, Birkhauser, Basel, 2003, pp. 1-10.

[10] I. Turel, "The Interactions of Metal Ions with Quinolone Antibacterial Agents," Coordination Chemistry Reviews, Vol. 232, No. 1-2, 2002, pp. 27-47. doi:10.1016/S0010-8545(02)00027-9

[11] B. E. Scully, M. Nakatomi, C. Ores, S. Davidson, H. C. Neu, "Ciprofloxacin Therapy in Cystic Fibrosis," The American Journal of Medicine, Vol. 82, No. 4A, 1987, pp. 196-201.

[12] Z. A. Siddiqi, M. Khalid, S. Kumar, M. Shahid and S. Noor, "Antimicrobial and SOD Activities of Novel Transition Metal Complexes of Pyridine-2,6-dicarboxylic Acid Containing 4-Picoline as Auxiliary Ligand," European Journal of Medicinal Chemistry, Vol. 45, No. 1, 2010, pp. 264-269. doi:10.1016/i.ejmech.2009.10.005

[13] S. Delaney, M. Pascaly, P. K. Bhattacharya, K. Han and J. K. Barton, "Oxidative Damage by Ruthenium Complexes Containing the Dipyridophenazine Ligand or Its Derivatives: A Focus on Intercalation," Inorganic Chemistry, Vol. 41, No. 7, 2002, pp. 1966-1974.

doi:10.1021/ic0111738

[14] K. Serbest, A. Colak, S. Güner, S. Karaböcek and F. Kormali, "Copper(II)-Manganese(II) Complexes of 3,3'-(1,3Propanediyldiimine)bis-(3-methyl-2-butanone)dioxime with Superoxide Dismutase-Like Activity," Transition Metal Chemistry, Vol. 26, No. 6, 2001, pp. 625-629. doi:10.1023/A:1012062510447

[15] A. I. Vogel, "Textbook of Practical Organic Chemistry," 5th Edition, Longman, London, 1989.

[16] G. Wanare, R. Aher, N. Kawathekar, R. Ranjan and N. K. Kaushik, "Synthesis of Novel $\alpha$-Pyranochalcones and Pyrazoline Derivatives as Plasmodium Falciparum Growth Inhibitors," Bioorganic \& Medicinal Chemistry Letters, Vol. 20, No. 15, 2010, pp. 4675-4678. doi:10.1016/j.bmcl.2010.05.069

[17] O. M. Abdelhafez, K. M. Amin, R. Z. Batran, T. J. Maher, S. A. Nada and S. Sethumadhvan, "Synthesis, Anticoagulant and PIVKA-II Induced by New 4-Hydroxycoumarin Derivatives Original Research Article," Bioorganic 
\& Medicinal Chemistry, Vol. 18, No. 10, 2010, pp. 33713378. doi:10.1016/j.bmc.2010.04.009

[18] D. H. Jani, H. S. Patel, H. Keharia and C. K. Modi, "Novel Drug-Based Fe(III) Heterochelates: Synthetic, Spectroscopic, Thermal and in-Vitro Antibacterial Significance," Applied Organometallic Chemistry, Vol. 24, No. 2, 2010, pp. 99-111.

[19] R. Wise, J. M. Andrews and J. P. Ashby, "Activity of Daptomycin against Gram-Positive Pathogens: A Comparison with Other Agents and the Determination of a Tentative Breakpoint," Journal of Antimicrobial Chemotherapy, Vol. 48, No. 4, 2001, pp. 563-567. doi: $10.1093 / \mathrm{jac} / 48.4 .563$

[20] I. F. F. Benziea and J. J. Strain, "The Ferric Reducing Ability of Plasma (FRAP) as a Measure of "Antioxidant Power': The FRAP Assay," Analytical Biochemistry, Vol. 239, No. 1, 1996, pp. 70-76. doi:10.1006/abio.1996.0292

[21] I. Kostova, G. Momekov, M. Zaharieva and M. Karaivanova, "Cytotoxic Activity of New Lanthanum (III) Complexes of Bis-Coumarins," European Journal of Medicinal Chemistry, Vol. 40, No. 6, 2005, pp. 542-551. doi:10.1016/j.ejmech.2004.12.007

[22] P. George, "Mononuclear Metal Complexes with Ciprofloxacin: Synthesis, Characterization and DNA-Binding Properties," Journal of Inorganic Biochemistry, Vol. 102, No. 12, 2008, pp. 1798-1811.

[23] J. R. Anacona and I. J. Rodriguez, "Synthesis and AntiBacterial Activity of Cephalexin Metal Complexes," Journal of Coordination Chemistry, Vol. 57, No. 15, 2004, pp. 1263-1269. doi:10.1080/00958970410001721411

[24] I. Leban, I. Turel and N. Bukovec, "Crystal Structure and Characterization of the Bismuth(III) Compound with Quinolone Family Member (Ciprofloxacin). Antibacterial Study," Journal of Inorganic Biochemistry, Vol. 66, No. 4, 1997, pp. 241-245. doi:10.1016/S0162-0134(96)00218-8

[25] K. S. Patel, J. C. Patel, H. R. Dholariya and K. D. Patel, "Multiple Heating Rate Kinetic Parameters, Thermal, X-Ray Diffraction Studies of Newly Synthesized Octahedral Copper Complexes Based on Bromo-Coumarins along with Their Antioxidant, Anti-Tubercular and Antimicrobial Activity Evaluation," Spectrochimica Acta Part A: Molecular and Biomolecular Spectroscopy, Vol. 96, 2012, pp. 468-479. doi:10.1016/j.saa.2012.05.057

[26] J. C. Patel, H. R. Dholariya, K. S Patel and K. D. Patel, "Spectral, Thermal, Biological and Multi-Heating Rate Kinetic Properties of $\mathrm{Cu}$ (II) Complexes Containing $\mathrm{N}_{2} \mathrm{O}_{2}$ Donor Ligands: 1,10-Phenanthroline and Acyl Coumarins," Applied Organometallic Chemistry.

[27] P. K. Panchal and M. N. Patel, "Toxic Effect of Transition Metal Complexes on Salmonella Typhi, Escherichia Coli and Serratia Marcescens," Toxicological \& Environmental Chemistry, Vol. 87, No. 3, 2005, pp. 407-414. doi:10.1080/02772240500254788

[28] K. B. Gudasi, M. S. Patil, R. S. Vadavi, R. V. Shenoy, S. A. Patil and M. Nethaji, "X-Ray Crystal Structure of the N-(2-hydroxy-1-naphthalidene)phenylglycine Schiff Base. Synthesis and Characterization of Its Transition Metal Complexes," Chemistry and Materials Science, Vol. 31, No. 5, 2006, pp. 580-585.

[29] K. C. Patel and D. E. Goldberg, “Aralkylpolyamine Complexes-III: Some Thiocyanate and Selenocyanate Complexes of Copper(II), Nickel(II) and Cobalt(II) with n-benzylethylenediamine and N,N'-dibenzylethylenediamine," Journal of Inorganic and Nuclear Chemistry, Vol. 34, No. 2, 1972, pp. 637-649. doi:10.1016/0022-1902(72)80444-5

[30] A. L. Abuhijleh, C. Woods and I. Y. Ahmed, "Synthesis and Molecular Structure of Monomeric Copper(II) Acetates with 2-Methylimidazole and 1,2-Dimethylimidazole," Inorganica Chimica Acta, Vol. 190, No. 1, 1991, pp. 11-17. doi:10.1016/S0020-1693(00)80226-1

[31] D. P. Singh, R. Kumar, V. Malik and P. Tyagi, "Synthesis and Characterization of Complexes of $\mathrm{Co}(\mathrm{II}), \mathrm{Ni}(\mathrm{II})$, $\mathrm{Cu}(\mathrm{II}), \mathrm{Zn}(\mathrm{II})$, and $\mathrm{Cd}(\mathrm{II})$ with Macrocycle 3,4,11,12Tetraoxo-1,2,5,6,9,10,13,14-octaaza-cyclohexadeca-6,8, 14,16-tetraene and Their Biological Screening," Transition Metal Chemistry, Vol. 32, No. 8, 2007, pp. 10511055.

[32] M. C. Jain, A. K. Shrivastava and P. C. Jain, "Some Tetragonally Distorted Copper(II) Complexes of 4-Benzylamidothiosemicarbazide and Its Thiosemicarbazone," Inorganica Chimica Acta, Vol. 23, 1977, pp. 199-203. doi:10.1016/S0020-1693(00)94761-3

[33] E. Canpolat, A. Yciazi and M. Kaya, "Synthesis and Characterization of Mononuclear Cobalt(II), Nickel(II), Copper(II), Zinc(II), Cadmium(II) and Dinuclear Uranyl(VI) Complexes with $N, N$-bis(2-\{[(2,2-dimethyl-1,3-dioxolan4-yl)methyl]amino butyl) $N$ ', $N$ '-dihydroxyethanediimidamide," Transition Metal Chemistry, Vol. 31, No. 3, 2006, pp. 653-657. doi:10.1007/s11243-006-0042-0

[34] A. M. Rahman, M. I. Choudhary and W. J. Thomsen, "Bioassay Techniques for Drug Development," Harwood Academic, Netherlands, 2001.

[35] J. Lv, T. T. Liu, S. Cai, X. Wang, L. Liu and Y. M. Wang, "Synthesis, Structure and Biological Activity of Cobalt(II) and Copper(II) Complexes of Valine-Derived Schiff Bases," Journal of Inorganic Biochemistry, Vol. 100, No. 11, 2006, pp. 1888-1096. doi:10.1016/j.jinorgbio.2006.07.014

[36] Z. H. Chohan, C. T. Supuran and A. Scozzafava, "Metalloantibiotics: Synthesis and Antibacterial Activity of Cobalt(II), Copper(II), Nickel(II) and Zinc(II) Complexes of Kefzol," Journal of Enzyme Inhibition and Medicinal Chemistry, Vol. 19, No. 1, 2004, pp. 79-84. doi:10.1080/14756360310001624939 